\title{
Comparative study between Ondansetron, Alizapride and Dexamethasone in Prevention of Postoperative Nausea and Vomiting in Laparoscopic Surgery
}

Ismail A. Shabaik, Hamed A. Sanad, Mohamed A. Abdel-Halim, Amr M. Zaki

Department of Anesthesiology and Intensive Care, Faculty of Medicine, Al-Azhar University

Corresponding author: Amr Mohamed Zaki Mohamed, Mobile: 01099649136;

Email: amrzaki2001189@gmail.com

\section{ABSTRACT}

Background: Post-operative nausea and vomiting (PONV) is a common cause of post-operative discomfort with incidence ranges from (50\%-70\%) after laparoscopic surgery.

Objective: To compare the effectiveness of dexamethasone, ondansetron and alizapride as monotherapy administered intravenously in postoperative nausea and vomiting prophylaxis for patients with moderate to high risk for nausea and vomiting undergoing laparoscopic surgery under general anesthesia.

Patients and Methods: The study population was 120 Egyptian patients from both sexes undergoing laparoscopic surgery under general anesthesia with endotracheal intubation at Al-Azhar University Hospitals (El Hussein Hospital and Bab Al-Sharya Hospital). Approval of the study was taken from the Ethics Committee of Al-Azhar University. Prior to initiation of the study, written informed consent of the patient was obtained after full explanation of elements contained in the research protocol. There were 4 study groups; Control group, ondansetron group, alizapride group and dexamethasone group.

Results: Age, sex, smoking history, related history, duration of surgery, type of surgery,

vital signs and postoperative pain severity did not have any significant value in our study. Comparing the 4 studied groups according to postoperative nausea and vomiting presence, time of incidence and number of episodes had a significant value.

Conclusion: Intravenous $0.1 \mathrm{mg} / \mathrm{kg}$ of ondansetron is very safe and highly significant in control of postoperative nausea and vomiting (PONV), it is even more effective than using $50 \mathrm{mg}$ of intravenous alizapride or $8 \mathrm{mg}$ of intravenous dexamethasone as prophylaxis. Dexamethasone is slightly better than alizapride in control of postoperative nausea and vomiting.

Keywords: Dexamethasone, Ondansetron, Alizapride, laparoscopic surgery, post-anesthetic care unit.

\section{INTRODUCTION}

Postoperative nausea and vomiting (PONV) is a common cause of postoperative discomfort and its incidence rate ranges from (50\%-70\%) after laparoscopic surgery ${ }^{(\mathbf{1})}$. Risk factors include opioid analgesic drugs, postoperative pain, the anesthetic agent or anesthesia technique, sudden movement or positional changes of the patient, a history of motion sickness, hypotension, the site of surgical operation, day of menstrual cycle and estrogen level ${ }^{(2)}$.

The best scoring system for PONV has been argued. The Apfel score; age $<50$ years, female, nonsmoking, and history of PONV, and opioid administration has become highly accepted ${ }^{(3)}$.

The Sinclair score includes duration and type of surgery as well. The risk factors for PONV also been assessed by Apfel group. These include female patients, younger than 50 years, history of nausea and/or vomiting after anesthesia and opioid intake ${ }^{(4)}$.

Hypotension and bradycardia may trigger emesis ${ }^{(5)}$. A liberal crystalloid regime reduces PONV risk ${ }^{(6}$. Fasting 6 hours for food and 2 hours for clear liquor exhibits explicit benefits, e.g. reduced $\mathrm{PONV}^{(7)}$.

Complete opioid free anesthesia has a reducing effect of PONV ${ }^{(8)}$. A long surgical period may have a great impact on PONV in women who undergo laparoscopic surgery ${ }^{(9)}$.

The duration of nitrous oxide exposure seems to have an impact; less than 1 hour use as part of the fresh gas has not been shown to increase the risk ${ }^{(\mathbf{1 0})}$.

The relative risk of nausea and vomiting is four times higher during menses; days one to eight of the menstrual cycle ${ }^{(\mathbf{1 1})}$. Female gender is associated to more PONV than men ${ }^{(12)}$. Non-smoking and younger age are well-known high risk factors for PONV ${ }^{(13)}$.

Ondansetron is a selective 5-hydroxytryptamine receptor antagonist with potent antiemetic activities. Its clearance half-time is 3.2-3.9 hours and a single dose of ondansetron provides long antiemetic effects. Ondansetron is effective in preventing post-operative nausea and vomiting (PONV) after laparoscopic, orthopedic, gynecologic, thyroid, and ophthalmic surgeries. The best dose for PONV prophylaxis is a single 4 $\mathrm{mg}$ bolus of I.V. ondansetron ${ }^{(14)}$.

The $\mathrm{D}_{2}$-receptor antagonist alizapride is a methoxy-2-benzamide derivative structurally related to metoclopramide ${ }^{(15)}$. Alizapride is a wellestablished antiemetic which is widely used in oncology and perioperative medicine ${ }^{(\mathbf{1 6})}$.

Since the mid 1980s, studies have stated that dexamethasone can decreases vomiting in patients after chemotherapy ${ }^{\left({ }^{(17)}\right.}$. Subsequent studies have also found that dexamethasone effectively 
prevents PONV induced by epidural morphine which is used to reduce post-operative pain ${ }^{(\mathbf{1 8})}$.

\section{AIM OF THE WORK}

To compare the effectiveness of dexamethasone, ondansetron and alizapride as monotherapy administered intravenously in postoperative nausea and vomiting prophylaxis for patients with moderate to high risk for nausea and vomiting undergoing laparoscopic surgery under general anesthesia.

\section{PATIENTS AND METHODS}

Patients: The study population was 120 Egyptian patients from both sexes undergoing laparoscopic surgery under general anesthesia with endotracheal intubation at Al-Azhar University Hospitals (El Hussein Hospital and Bab Al-Sharya Hospital): Approval of the study was taken from the Ethics Committee of Al-Azhar University. Prior to initiation of the study, written informed consent of the patient was obtained after full explanation of elements contained in the research protocol.

Study design: This is a single-center, open-label, double blinded prospective, randomized study. The patients, health care providers included in the patient care, the person who collected and analyzed data, and the outcome adjudicators were unaware of the treatment group allocation.

Randomization: Randomization was done through opaque and well-sealed envelopes. The sequence generation was done by computer. Number was written on envelope and group was written on the card within it along with the serial number. When a patient comes, an envelop was opened to see the group to be allotted. Patients were randomly allocated to receive a single dose of ondansetron, alizapride, dexamethasone or normal saline.

Study Groups: - Control group: received $10 \mathrm{ml}$ of normal saline. Ondansetron group: received $0.1 \mathrm{mg} / \mathrm{kg}$ of ondansetron. Alizapride group: received $50 \mathrm{mg}$ of alizapride. Dexamethasone group: received $8 \mathrm{mg}$ of dexamethasone.

Assignment of Interventions: Medications were administered in a $10 \mathrm{ml}$ syringe. Syringes were labeled with a study-specific identification i.e. a number for each patient. The anesthetist administered the study medication and was unaware of the distribution of the treatment groups.

Inclusion Criteria: Patients with age between 18-60 years. Weight between 50-120 kg. Patients who were planned for laparoscopic surgery under GA. American Society of Anesthesiologists (ASA) I-II.

Exclusion Criteria Patients with history of gastrointestinal hemorrhage. Patients who developed nausea and vomiting on the last day on prior surgery. Patients who received antiemetic drugs within 24 hours on prior surgery. Conversion to open cholecystectomy. Patients with previous history of drug reaction to any of the drug used in the present study. Patients with less than 6 hours fasting. Patients who were taking corticosteroids. Patients with any pathology that causes preoperative nausea or vomiting. Patients with ASA score III or more. Patients below 18 years and above 60 years old. Patients with history of severe hypotension.

Patients' assessments: All patients were subjected to perioperative assessment which will include: -Preoperative assessment (In outpatient clinic center). Intraoperative assessment (After induction of anesthesia). Postoperative assessment (In postoperative care unit).

Preoperative assessment: - Age. Sex. Diagnosis. Type of laparoscopic surgery. History of motion sickness, taking anti-emetic drugs, repeated nausea and vomiting, any pathology that increases or decreases the risk of PONV, and smoking.

Intraoperative assessment: Oxygenation. Blood pressure. Pulse. Duration of surgery. Unusual intraoperative events during the surgery.

Postoperative assessment: - Presence of nausea. Presence of vomiting. Amount and frequency of vomiting. Specific characters of vomitus. Time of vomiting incidence. Presence of postoperative pain. Intensity of postoperative pain. Amount of rescue anti-emetics needed postoperatively. Amount of analgesics needed postoperatively.

\section{Data analysis}

All the observed parameters and results were carefully recorded and analyzed statistically. Data were fed to the computer and analyzed using IBM SPSS software package version 20.0. (Armonk, NY: IBM Corp): Qualitative data were described using number and percent. Significance of the obtained results was judged at the (5\%) level.

The used tests were:- Chi-square test:

For categorical variables, to compare between different groups. Monte Carlo correction: Correction for chi-square when more than (20\%) of the cells have expected count less than 5. F-test (ANOVA): For normally distributed quantitative variables, to compare means of more than 2 groups. 
Ismail A. Shabaik et al.

\section{RESULTS}

Table (1): Distribution of the studied cases

\begin{tabular}{|l|c|c|}
\hline & No. & \% \\
\hline Total & $\mathbf{1 2 0}$ & $\mathbf{1 0 0 . 0}$ \\
Included patients & $\mathbf{1 0 0}$ & $\mathbf{8 3 . 3}$ \\
Saline & 25 & 20.8 \\
Ondansetron & 25 & 20.8 \\
Alizapride & 25 & 20.8 \\
Dexamethasone & 25 & 20.8 \\
Excluded patients & $\mathbf{2 0}$ & $\mathbf{1 6 . 7}$ \\
ASA (III\& IV) & 10 & 8.3 \\
Lost follow & 2 & 1.7 \\
Refused to participate & 8 & 6.7 \\
\hline
\end{tabular}

Table (2): Comparison between the four studied groups according to sex

\begin{tabular}{||l|c|c|c|c|c|c||}
\hline Variables & $\begin{array}{c}\text { Control } \\
\text { group } \\
(\mathbf{n = 2 5})\end{array}$ & $\begin{array}{c}\text { Ondansetron } \\
\text { group } \\
(\mathbf{n = 2 5})\end{array}$ & $\begin{array}{c}\text { Alizapride } \\
\text { group } \\
(\mathbf{n = 2 5})\end{array}$ & $\begin{array}{c}\text { Dexamethasone } \\
\text { group } \\
(\mathbf{n = 2 5})\end{array}$ & $\chi^{\mathbf{2}}$ & $\begin{array}{c}\text { P- } \\
\text { value }\end{array}$ \\
\hline Sex & & & & & & \\
Male & $9(36.0 \%)$ & $12(48.0 \%)$ & $8(32.0 \%)$ & $10(40.0 \%)$ & 1.471 & 0.689 \\
Female & $16(64.0 \%)$ & $13(52.0 \%)$ & $17(68.0 \%)$ & $15(60.0 \%)$ & \\
\hline
\end{tabular}

$\chi^{2}$ : Chi square test Data presented as number (n) and percentage (\%)

$\mathrm{P}: \mathrm{p}$ value for comparing between the four studied groups

Table (3): Comparison between the four studied groups according to age

\begin{tabular}{|l|c|c|c|c|c|c||}
\hline Groups & $\begin{array}{c}\text { Control group } \\
(\mathbf{n = 2 5})\end{array}$ & $\begin{array}{c}\text { Ondansetron } \\
\text { group } \\
(\mathbf{n = 2 5})\end{array}$ & $\begin{array}{c}\text { Alizapride } \\
\text { group } \\
(\mathbf{n = 2 5})\end{array}$ & $\begin{array}{c}\text { Dexamethasone } \\
\text { group } \\
(\mathbf{n = 2 5})\end{array}$ & F & $\begin{array}{c}\text { P - } \\
\text { value }\end{array}$ \\
\hline $\begin{array}{l}\text { Age (years) } \\
\text { Mean } \pm \text { SD. }\end{array}$ & $34.64 \pm 10.76$ & $39.04 \pm 10.04$ & $39.16 \pm 8.72$ & $37.92 \pm 9.74$ & 1.148 & 0.334 \\
\hline
\end{tabular}

$\mathrm{F}$ : $\mathrm{F}$ for ANOVA test , P: $\mathrm{p}$ value for comparing between the four studied groups

Data presented as mean \pm standard deviation $(\mathrm{M} \pm \mathrm{SD})$

Table (4): Comparison between the 4 studied groups according to related history.

\begin{tabular}{||l|c|c|c|c|c|c||}
\hline \hline Groups & $\begin{array}{c}\text { Control } \\
\text { group } \\
(\mathbf{n = 2 5})\end{array}$ & $\begin{array}{c}\text { Ondansetron } \\
\text { group } \\
(\mathbf{n = 2 5})\end{array}$ & $\begin{array}{c}\text { Alizapride } \\
\text { group } \\
(\mathbf{n = 2 5})\end{array}$ & $\begin{array}{c}\text { Dexamethasone } \\
\text { group } \\
(\mathbf{n = 2 5})\end{array}$ & $\chi^{\mathbf{2}}$ & $\begin{array}{c}\text { P - } \\
\text { value }\end{array}$ \\
\hline ASA Score & $10(40.0 \%)$ & $9(36.0 \%)$ & $13(52.0 \%)$ & $8(32.0 \%)$ & 2.333 & 0.506 \\
I & $15(60.0 \%)$ & $16(64.0 \%)$ & $12(48.0 \%)$ & $17(68.0 \%)$ & & \\
II & $21(84.0 \%)$ & $21(84.0 \%)$ & $21(84.0 \%)$ & $22(88.0 \%)$ & 0.388 & $\begin{array}{c}\mathrm{MC}_{\mathrm{p}=} \\
4(16.0 \%)\end{array}$ \\
\hline $\begin{array}{l}\text { Surgery type } \\
\text { Lap Chol. } \\
\text { Gastric sleeve }\end{array}$ & $4(16.0 \%)$ & $4(16.0 \%)$ & $3(12.0 \%)$ & 1.0 \\
\hline $\begin{array}{l}\text { Motion sickness } \\
\text { history }\end{array}$ & $7(28.0 \%)$ & $5(20.0 \%)$ & $10(40.0 \%)$ & $10(40.0 \%)$ & 3.309 & 0.346 \\
\hline Antiemetics history & $7(28.0 \%)$ & $5(20.0 \%)$ & $10(40.0 \%)$ & $10(40.0 \%)$ & 3.309 & 0.346 \\
\hline $\begin{array}{l}\text { Frequent nausea } \\
\text { and vomiting } \\
\text { history }\end{array}$ & $7(28.0 \%)$ & $5(20.0 \%)$ & $10(40.0 \%)$ & $10(40.0 \%)$ & 3.309 & 0.346 \\
\hline Smoking history & $5(20.0 \%)$ & $11(44.0 \%)$ & $7(28.0 \%)$ & $8(32.0 \%)$ & 3.506 & 0.320 \\
\hline
\end{tabular}

$\chi 2$ : Chi square test MC : Monte Carlo test Data presented as number (n) \& percentage (\%), P: $\mathrm{p}$ value for comparing between the four studied groups 
Table (5): Comparison between the four studied groups according to intraoperative assessment

\begin{tabular}{||l|c|c|c|c|c|c||}
\hline \multicolumn{1}{|c|}{ Groups } & $\begin{array}{c}\text { Control } \\
\text { group } \\
\text { Variables }\end{array}$ & $\begin{array}{c}\text { Ondansetron } \\
\text { group } \\
(\mathbf{n = 2 5})\end{array}$ & $\begin{array}{c}\text { Alizapride } \\
\text { group } \\
(\mathbf{n = 2 5})\end{array}$ & $\begin{array}{c}\text { Dexamethasone } \\
\text { group } \\
(\mathbf{n = 2 5})\end{array}$ & $\begin{array}{c}\text { Test of } \\
\text { Sig. }\end{array}$ & P-value \\
\hline $\begin{array}{l}\text { Systolic blood } \\
\text { pressure (mmHg) } \\
\text { Mean } \pm \text { SD. }\end{array}$ & $96.40 \pm 4.90$ & $96.0 \pm 5.0$ & $96.0 \pm 5.0$ & $96.0 \pm 5.0$ & $\begin{array}{c}\mathrm{F}= \\
0.040\end{array}$ & 0.989 \\
\hline $\begin{array}{l}\text { Diastolic blood } \\
\text { pressure (mmHg) } \\
\text { Mean } \pm \text { SD. }\end{array}$ & $56.40 \pm 4.90$ & $56.0 \pm 5.0$ & $56.0 \pm 5.0$ & $56.0 \pm 5.0$ & $\begin{array}{c}\mathrm{F}= \\
0.040\end{array}$ & 0.989 \\
\hline $\begin{array}{l}\text { Duration of surgery } \\
\text { 1 hour }\end{array}$ & $\begin{array}{l}21(84.0 \%) \\
(16.0 \%)\end{array}$ & $\begin{array}{c}21(84.0 \%) \\
(16.0 \%)\end{array}$ & $\begin{array}{c}21(84.0 \%) \\
16.0 \%)\end{array}$ & $\begin{array}{c}22(88.0 \%) \\
3(12.0 \%)\end{array}$ & $\begin{array}{c}\chi^{2}= \\
0.388\end{array}$ & ${ }_{\mathrm{pC}}=$ \\
\hline
\end{tabular}

$\chi^{2}$ : Chi square test $\quad$ MC: Monte Carlo test

F: F for ANOVA test

P: $p$ value for comparing between the four studied groups

Data presented as mean \pm standard deviation $(\mathrm{M} \pm \mathrm{SD})$ and number $(\mathrm{n})$ and percent $(\%)$

Table (6): Comparison between the four studied groups according to postoperative nausea

\begin{tabular}{|c|c|c|c|c|c|c|}
\hline$\underbrace{\text { Groups }}_{\text {Variables }}$ & $\begin{array}{c}\text { Control } \\
\text { group } \\
(\mathbf{n}=\mathbf{2 5})\end{array}$ & $\begin{array}{c}\text { Ondansetron } \\
\text { group } \\
(\mathbf{n}=\mathbf{2 5})\end{array}$ & $\begin{array}{l}\text { Alizapride } \\
\text { group } \\
(\mathbf{n}=\mathbf{2 5})\end{array}$ & $\begin{array}{l}\text { Dexamethasone } \\
\text { group } \\
(\mathbf{n}=\mathbf{2 5})\end{array}$ & $\chi^{2}$ & $\begin{array}{c}P \text { - } \\
\text { value }\end{array}$ \\
\hline Presence & $13(52.0 \%)$ & $4(16.0 \%)$ & $7(28.0 \%)$ & $6(24.0 \%)$ & $8.571^{*}$ & 0.036 \\
\hline Sig. bet. Groups & $\mathrm{p}_{1}=0.007$ & $\mathrm{p}_{2}=0.083, \mathrm{p}_{3}=0$ & $1^{*}, \mathrm{p}_{4}=0.306$ & $=0.480, \mathrm{p}_{6}=0.747$ & & \\
\hline $\begin{array}{l}\text { Time } \\
1^{\text {st }} \\
2^{\text {nd }}\end{array}$ & $\begin{array}{l}11(84.6 \%) \\
2(15.4 \%)\end{array}$ & $\begin{array}{l}3(75.0 \%) \\
1(25.0 \%)\end{array}$ & $\begin{array}{l}6(85.7 \%) \\
1(14.3 \%)\end{array}$ & $\begin{array}{l}4(66.7 \%) \\
2(33.3 \%)\end{array}$ & 1.491 & $\begin{array}{l}{ }^{\mathrm{MC}} \mathrm{p}= \\
0.789\end{array}$ \\
\hline $\begin{array}{l}\text { Episodes number } \\
1\end{array}$ & $13(100.0 \%)$ & $4(100.0 \%)$ & $7(100.0 \%)$ & $6(100.0 \%)$ & - & - \\
\hline
\end{tabular}

$\chi^{2}$ : Chi square test $\quad$ MC : Monte Carlo test Data presented as number (n) and percentage (\%)

$\mathrm{P}: \mathrm{p}$ value for comparing between the four studied groups

p1: $p$ value for comparing between control group and Ondansetron group

$\mathrm{p} 2: \mathrm{p}$ value for comparing between Saline group and Alizapride group

p3: $p$ value for comparing between Saline group and Dexamethasone group

p4: $p$ value for comparing between Ondansetron group and Dexamethasone group

p5: $p$ value for comparing between Ondansetron group and Alizapride group

p6: $p$ value for comparing between Dexamethasone group and Alizapride group

*: Statistically significant at $\mathrm{p} \leq 0.05$ 
Ismail A. Shabaik et al.

Table (7): Comparison between the four studied groups according to postoperative vomiting.

\begin{tabular}{|c|c|c|c|c|c|c|}
\hline Variables & $\begin{array}{c}\text { Control } \\
\text { group } \\
(\mathbf{n}=\mathbf{2 5}) \\
\end{array}$ & $\begin{array}{c}\text { Ondansetron } \\
\text { group } \\
(\mathbf{n}=\mathbf{2 5}) \\
\end{array}$ & $\begin{array}{c}\text { Alizapride } \\
\text { group } \\
(\mathbf{n}=\mathbf{2 5}) \\
\end{array}$ & $\begin{array}{l}\text { nethasone group } \\
(n=25)\end{array}$ & $\chi^{2}$ & P- value \\
\hline Presence & $13(52.0 \%)$ & $4(16.0 \%)$ & $7(28.0 \%)$ & $6(24.0 \%)$ & $8.571^{*}$ & $0.036^{*}$ \\
\hline Sig. bet. Grps & \multicolumn{4}{|c|}{$\mathrm{p}_{1}=0.007^{*}, \mathrm{p}_{2}=0.083, \mathrm{p}_{3}=0.041^{*}, \mathrm{p}_{4}=0.306, \mathrm{p}_{5}=0.480, \mathrm{p}_{6}=0.747$} & & \\
\hline $\begin{array}{l}\text { Time } \\
1^{\text {st }} \\
2^{\text {nd }}\end{array}$ & $\begin{array}{c}11(84.6 \%) \\
2(15.4 \%)\end{array}$ & $\begin{array}{l}3(75.0 \%) \\
1(25.0 \%)\end{array}$ & $\begin{array}{l}6(85.7 \%) \\
1(14.3 \%)\end{array}$ & $\begin{array}{l}4(66 \\
2(33\end{array}$ & 1.491 & $\begin{array}{l}{ }^{\mathrm{MC}} \mathrm{p}= \\
0.789\end{array}$ \\
\hline $\begin{array}{l}\text { Episodes number } \\
1 \\
2\end{array}$ & $\begin{array}{c}11(84.6 \%) \\
2(15.4 \%)\end{array}$ & $\begin{array}{l}3(75.0 \%) \\
1(25.0 \%)\end{array}$ & $\begin{array}{l}6(85.7 \%) \\
1(14.3 \%)\end{array}$ & $\begin{array}{l}5(8 \\
1(1\end{array}$ & 0.894 & $\begin{array}{l}{ }^{\mathrm{MC}} \mathrm{p}= \\
1.000\end{array}$ \\
\hline Rescue anti-emetics & $13(52.0 \%)$ & $4(16.0 \%)$ & $7(28.0 \%)$ & $6(24.0 \%)$ & $8.571^{*}$ & $0.036^{*}$ \\
\hline Sig. bet. Grps & \multicolumn{4}{|c|}{$\mathrm{p}_{1}=0.007^{*}, \mathrm{p}_{2}=0.083, \mathrm{p}_{3}=0.041^{*}, \mathrm{p}_{4}=0.306, \mathrm{p}_{5}=0.480, \mathrm{p}_{6}=0.747$} & & \\
\hline
\end{tabular}

$\chi^{2}$ : Chi square test $\quad$ MC: Monte Carlo test Data presented as number (n) \& percentage (\%)

P: $p$ value for comparing between the four studied groups

$\mathrm{p} 1 \mathrm{p}$ value for comparing between control group and Ondansetron group

p2: $p$ value for comparing between control group and Alizapride group

p3: $\mathrm{p}$ value for comparing between control group and Dexamethasone group

$\mathrm{p} 4: \mathrm{p}$ value for comparing between Ondansetron group and Dexamethasone group

$\mathrm{p} 5$ : $\mathrm{p}$ value for comparing between Ondansetron group and Alizapride group

p6: $\mathrm{p}$ value for comparing between Dexamethasone group and Alizapride group

*: Statistically significant at $\mathrm{p} \leq 0.05$

Table (8): Comparison between the four studied groups according to postoperative pain severity

\begin{tabular}{||l|c|c|c|c|c|c||}
\hline Gariables & $\begin{array}{c}\text { Control } \\
\text { group } \\
(\mathbf{n = 2 5})\end{array}$ & $\begin{array}{c}\text { Ondansetron } \\
\text { group } \\
(\mathbf{n = 2 5})\end{array}$ & $\begin{array}{c}\text { Alizapride } \\
(\mathbf{n = 2 5})\end{array}$ & $\begin{array}{c}\text { Dexamethasone } \\
\text { group } \\
(\mathbf{n = 2 5})\end{array}$ & $\chi^{\mathbf{2}}$ & $\begin{array}{c}\text { P- } \\
\text { value }\end{array}$ \\
\hline Severity & $0(0.0 \%)$ & $0(0.0 \%)$ & $1(4.0 \%)$ & $0(0.0 \%)$ & & \\
No & $16(64.0 \%)$ & $22(88.0 \%)$ & $16(64.0 \%)$ & $15(60.0 \%)$ & 8.759 & 0.123 \\
Mild to moderate & $9(36.0 \%)$ & $3(12.0 \%)$ & $8(32.0 \%)$ & $10(40.0 \%)$ & & \\
Severe & $9(36.0 \%)$ & $3(12.0 \%)$ & $8(32.0 \%)$ & $10(40.0 \%)$ & 5.524 & 0.137 \\
\hline Rescue analgesic & 9
\end{tabular}

$\chi 2$ : Chi square test Data presented as number $(\mathrm{n}) \&$ percentage $(\%)$

$\mathrm{P}: \mathrm{p}$ value for comparing between the four studied groups

Table (9): Relation between PONV and risk factors.

\begin{tabular}{|c|c|c|c|c|}
\hline & \multicolumn{2}{|c|}{ Nausea and Vomiting } & \multirow[b]{2}{*}{$\chi^{2}$} & \multirow[b]{2}{*}{$\mathbf{P}$} \\
\hline & $\begin{array}{c}\text { No } \\
(n=70)\end{array}$ & $\begin{array}{c}\text { Yes } \\
(\mathbf{n}=30)\end{array}$ & & \\
\hline Motion sickness history & $8(11.4 \%)$ & $24(80.0 \%)$ & $45.378^{*}$ & $<0.001^{*}$ \\
\hline Anti-emetics history & $8(11.4 \%)$ & $24(80.0 \%)$ & $45.378^{*}$ & $<0.001^{*}$ \\
\hline Frequent nausea \& vomiting history & $8(11.4 \%)$ & $24(80.0 \%)$ & $45.378^{*}$ & $<0.001^{*}$ \\
\hline Non-smoking history & $41(58.6 \%)$ & $28(93.3 \%)$ & $11.864^{*}$ & $0.001^{*}$ \\
\hline $\begin{array}{l}\text { Severity: No } \\
\text { Mild to moderate } \\
\text { Severe }\end{array}$ & $\begin{array}{c}0(0.0 \%) \\
62(88.6 \%) \\
8(11.4 \%)\end{array}$ & $\begin{array}{c}1(3.3 \%) \\
7(23.3 \%) \\
22(73.3 \%)\end{array}$ & $40.936^{*}$ & $\begin{array}{c}{ }^{\mathrm{MC}} \mathrm{p} \\
<0.001^{*}\end{array}$ \\
\hline $\begin{array}{l}\text { Surgery duration: } 1 \text { hour } \\
2 \text { hour }\end{array}$ & $\begin{array}{c}69(98.6 \%) \\
1(1.4 \%)\end{array}$ & $\begin{array}{l}16(53.3 \%) \\
14(46.7 \%)\end{array}$ & $33.707^{*}$ & $\begin{array}{c}\mathrm{FE}_{\mathrm{p}} \\
<0.001^{*}\end{array}$ \\
\hline Sex: Male & $\begin{array}{l}36(51.4 \%) \\
34(48.6 \%)\end{array}$ & $\begin{array}{l}3(10.0 \%) \\
27(90.0 \%)\end{array}$ & $15.150^{*}$ & $<0.001^{*}$ \\
\hline
\end{tabular}


$\chi^{2}$ : Chi square test Data presented as number (n) \& percentage $(\%)$

$\mathrm{P}: \mathrm{p}$ value for comparing between the four studied groups

\section{DISCUSSION}

In our study, age did not constitute a significant risk factor. Neither did we observe that the incidence of PONV depended on the gender, type of laparoscopic surgery, ASA score or surgery duration. History of motion sickness, frequent vomiting, antiemetics intake or smoking did not show any significant difference in our study.

Masoomeh et al. ${ }^{\left({ }^{19)}\right.}$ found in a similar study that age and surgery duration did not show any significant difference.

It was noted that PONV occurred less frequently in the groups administered antiemetic drugs than in the control group. Patients of control group had the highest rate of PONV and requested rescue anti-emetics in 13 patients out of 25 with percentage of $(52 \%)$. Our results are congruent with a previous study by Langevin $\boldsymbol{e t}$ al. ${ }^{(20)}$

The best results were obtained in the group in which we administered ondansetron, whereas the worst results were observed in the control group that received normal saline.

In ondansetron group only (16\%) of patients had postoperative nausea and vomiting. In dexamethasone group (24\%) of patient presented with nausea and vomiting. In alizapride group (28\%) of patients had postoperative nausea and vomiting.

Similar results were reported by Masoomeh et al. ${ }^{\left({ }^{(19)}\right.}$ nausea was found in 72 out of 126 patients with an incidence rate of $(20.8 \%)$ in the ondansetron, $(23.6 \%)$ in the dexamethasone, (25.0\%) in the metoclopramide, and $(30.5 \%)$ in the control groups. Vomiting was found in 49 patients with an incidence rate of $(8.1 \%),(16.3 \%),(36.7 \%)$ and $(38.7 \%)$ in ondansetron, dexamethasone, metoclopramide and control groups, respectively.

In a study by Ho et al. ${ }^{(21)}$ the occurrence of vomiting and nausea was the most common in the control group compared with the dexamethasone, ondansetron and the granisetron groups, and the lowest rate was observed in dexamethasone group. Wu et al. ${ }^{(22)}$ reported that ondansetron was the most effective in the prevention of nausea and vomiting.

\section{CONCLUSION}

Intravenous $0.1 \mathrm{mg} / \mathrm{kg}$ of ondansetron is very safe and highly significant in control of PONV. It is even more effective than using $50 \mathrm{mg}$ of intravenous alizapride or $8 \mathrm{mg}$ of intravenous dexamethasone as prophylaxis. Dexamethasone is slightly better than alizapride in control of postoperative nausea and
MC : Monte Carlo test

vomiting. Both alizapride and dexamethasone are definitely better than using normal saline. The highest rate of PONV was among the control group of normal saline.

\section{REFERENCES}

1. Gan TJ, Collins, Hetreed M (1994): Double blind comparison of ondansetron, droperidol and saline in the prevention of post-operative nausea and vomiting. Br J Anesthesia, 72:544-547.

2. Wetchler BV (1991): Problem solving in the post anesthesia care unit. In: Wetchler BV, ed. Anesthesia for ambulatory surgery 2nd edn. Philadelphia: JB Lippincott, pp 375-436.

3. Eberhart LH, Ogel JH, Seeling W et al. (2000): Evaluation of three risk scores to predict postoperative nausea and vomiting, Acta Anesthesiol Scand., 44:480-488.

4. Apfel CC, Meyer A, Orhan-Sungur M et al. (2012): Supplemental intravenous crystalloids for the prevention of post-operative nausea and vomiting. $\mathrm{Br}$ J Anesth., 108: 893-902.

5. Naguib K, Osman HA, Al-Khayat HC et al. (1998): Prevention of post-operative nausea and vomiting following laparoscopic surgery ephedrine vs propofol. Middle East J Anesthesiol., 14:219-230.

6. Apfel CC, Philip BK, Cakmakkaya OS et al. (2012): Who is at risk of nausea and vomiting are clinically useful tools and should be used in every patient. EUR Anaesthesiol., 28:155-9.

7. Pimenta G, De Aguilar-Nascimento J(2014): Prolonged preoperative fasting in elective surgical patients: why should we reduce it? Nutr Clin Pract., 29: 22-28.

8. Ziemann-Gimmel P, Goldfarb AA, Koppman J et al. (2014): Opioid-free total intravenous anaesthesia reduces postoperative nausea and vomiting in bariatric surgery beyond triple prophylaxis. $\mathrm{Br} \mathrm{J}$ Anaesth., 112(5):906-11.

9. Tseng LH, Liou SC, Chang TC et al. (2006): A randomized blinded study of the incidence of postoperative nausea and vomiting in women after major gynecologic laparoscopic surgery. Invasive Gynecol., 13(5):413-7.

10. Peyton PJ, Wu CY (2014): Nitrous oxide related postoperative nausea and vomiting depends on duration of exposure. Anesthesiology, 120:11371145.

11. Beattie W, Lindbald T, Buckley DN (1991): The incidence of postoperative nausea and vomiting in women undergoing laparoscopy is influenced by the day of menstrual cycle. Can J Anesth., 38(3):298302.

12. Conti D, Ballo P, Boccalini $R$ et al. (2014): The effect of patient sex on the incidence of early adverse effects in a population of elderly patients, Anesth Intensive Care, 42:455-459. 
13. Neoh K, Adkinson L, Montgomery V et al. (2014): Management of nausea and vomiting in palliative care. Br J Hosp Med., 75:391-392.

14. Markham A, Sorkin EM (1993): Ondansetron an up to date of its therapeutic use in chemotherapyinduced and postoperative nausea and vomiting. Drugs, 45: 931-952.

15. Dewinter G, Teunkens A, Vermeulen $\mathrm{K}$ et al. (2016): Alizapride and ondansetron for the prevention of postoperative nausea and vomiting in patients undergoing laparoscopic gynecological surgery: A doubleblind, randomised, placebocontrolled non-inferiority study. Eur J Anesthesiol., 33(2):96-103.

16. Myklejord DJ, Yao L, Liang H et al. (2012): Consensus guideline adoption for managing postoperative nausea and vomiting. WMJ., 111 (5): 207-13.

17. Markman M, Sheidler V, Ettinger DS et al. (1984): Antiemetic efficacy of dexamethasone: randomized, doubleblind, crossover study with prochlorperazine in patients receiving cancer chemotherapy. N Engl J Med., 311:549-52.

18. Wang JJ, Ho ST, Liu HS et al. (2000): Prophylactic antiemetic effect of dexamethasone in women undergoing ambulatory laparoscopic surgery. Br J Anaesth., 84:459-62.

19. Masoomeh T, Hossein S, Alireza T et al. (2014): Comparative Study of the Effectiveness of Ondansetron, Metoclopramide and Low Dose Dexamethasone to Prevent Postoperative Nausea and Vomiting in Females who Undergo Laparoscopic Cholecystectomy. Womens Health Bull, 1(3):2266122664.

20.Langevin S, Lessard MR and Trepanier CA (1999): Alfentanil causes less postoperative nausea and vomiting than equipotent doses of fentanyl or sufentanil in outpatients. Anesthesiology, 91(6):1666-73.

21.Ho CM, Wu HL, Ho ST et al. (2011): Dexamethasone prevents postoperative nausea and vomiting: benefit versus risk. Acta Anesthesiol Taiwan, 49(3):100-4.

22. Wu SJ, Xiong XZ, Cheng TY et al. (2012). Efficacy of ondansetron vs. metoclopramide in prophylaxis of postoperative nausea and vomiting after laparoscopic cholecystectomy: a systematic review and metaanalysis. Hepatogastroenterology, 59(119):2064-74. 